\title{
WIDER
}

World Institute for Development Economics Research

\author{
Discussion Paper No. 2002/97
}

\section{Additionality of Debt Relief and Debt Forgiveness, and Implications for Future Volumes of Official Assistance}

\section{Léonce Ndikumana *}

October 2002

\begin{abstract}
This paper examines the impact of debt forgiveness and debt relief on official development assistance. From the recipient side, the econometric analysis suggests that countries that received debt relief also received more aid compared to those that did not qualify for debt relief. From the donor side, while the data indicate a decline in aid disbursement since the early 1990s, there is no econometric evidence for any direct causal relationship between the decline in aid and debt relief/forgiveness. Nonetheless, the decline in aid raises serious concerns given that developing countries' need in external resources cannot be met by debt relief alone.
\end{abstract}

Keywords: debt relief, debt forgiveness, official development aid, HIPC Initiative, crowding out

JEL classification: F34, F35, O11, O19

* Dept. of Economics, University of Massachusetts, Amherst

This study has been prepared within the UNU/WIDER project on the Sustainability of External Development Financing, which is directed by Matthew Odedokun.

This paper was presented at the project meeting in Helsinki, 23-24 August 2002.

UNU/WIDER gratefully acknowledges the financial contribution to the project by the Ministry for Foreign Affairs of Finland. 


\section{Acknowledgement}

The author is grateful for constructive comments and very helpful suggestions from Mansoob Murshed and Matthew Odedokun.

UNU World Institute for Development Economics Research (UNU/WIDER) was established by the United Nations University as its first research and training centre and started work in Helsinki, Finland in 1985. The purpose of the Institute is to undertake applied research and policy analysis on structural changes affecting the developing and transitional economies, to provide a forum for the advocacy of policies leading to robust, equitable and environmentally sustainable growth, and to promote capacity strengthening and training in the field of economic and social policy making. Its work is carried out by staff researchers and visiting scholars in Helsinki and through networks of collaborating scholars and institutions around the world.

UNU World Institute for Development Economics Research (UNU/WIDER)

Katajanokanlaituri 6 B, 00160 Helsinki, Finland

Camera-ready typescript prepared by Liisa Roponen at UNU/WIDER

Printed at UNU/WIDER, Helsinki

The views expressed in this publication are those of the author(s). Publication does not imply endorsement by the Institute or the United Nations University, nor by the programme/project sponsors, of any of the views expressed.

ISSN 1609-5774

ISBN 92-9190-320-5 (printed publication)

ISBN 92-9190-321-3 (internet publication) 
Aid can be like a widow's curse: it does not get wasted by expending more of it, but attempts to spare it can translate the curse into a Danaid jar which can never be filled up.

(UNCTAD 2000: 3)

\section{Introduction}

Since the late 1980s, the donor community initiated a series of strategies aimed at alleviating the burden of external debt on developing countries. The initial process involved non-concessional flow rescheduling of debt payments due, resulting in a transfer of the burden over time. This process was relatively costless for the creditors as it implied no accounting loss. In contrast, debtors did not benefit from rescheduling and their debt burden continued to increase. The Highly Indebted Poor Countries (HIPC) Initiative sponsored by the World Bank and the International Monetary Fund since 1996 aims at reducing the present value of the debt stock for countries that meet specific criteria. As of September 2002, a total of 27 countries have qualified for debt relief under the HIPC Initiative, including 24 countries from Sub-Saharan Africa (SSA). On the debtor side, progress with the HIPC Initiative is constrained by the slow pace of implementation of poverty-reducing programmes and other institutional bottlenecks. On the creditor side, the programme is hindered by the slow speed of delivery of debt relief and the fact that a number of non-Paris Club creditors have not yet committed to providing debt relief.

As a development financing strategy, debt relief is not likely to have significant effects unless other measures are taken to maintain - or even better - to increase the level of conventional development financing towards low-income countries. An increase in aid flows is the only way to help these countries to boost economic development and overcome debt crisis and aid dependence. The UNCTAD (2000: 2) points out that 'the only feasible way to end aid dependence is to launch a massive aid programme and to sustain rapid growth for a sufficiently long period so as to allow domestic savings and external private flows to gradually replace official aid'. There is ample evidence that shows that development assistance plays a net positive role in economic development, given the appropriate institutional environment (Burnside and Dollar 2000) and even independently of the institutional and policy environment (Hansen and Tarp 2001). ${ }^{1}$

The existing evidence indicates that the supply of ODA and grants by major donors has declined since the 1990s.From 1990 to 2000, aid to SSA countries as a group declined by 28 per cent, from US\$ 18 billion to US\$ 13 billion, or from US\$ 34 to US\$ 20 per capita (World Development Indicators 1997 and 2002). While debt relief may help in reducing the pressure of debt service on government budgets and on the balance of payments, the net gains in resources from debt relief alone will not be enough to meet the needs for development financing, especially given the fact that low-income

1 Hansen and Tarp (2001) discuss various issues related to the empirical analysis of the links between aid and growth as well as the role of the policy environment for the effectiveness of aid. In particular, they conclude that the claim by Burnside and Dollar (2000) that aid contributes to aid only in good policy environments is not supported by the data. 
countries are unable to attract substantial amounts of other forms of external financing such as private capital.

This study addresses the specific question of additionality of debt relief by examining whether and to what extent debt relief has been accompanied by a decrease in the flow of development aid, grants, and other forms of concenssional external financing. The study examines the effects of both traditional debt forgiveness and debt relief under the HIPC Initiative using data from both the donor side and the recipient side. ${ }^{2}$ From the donor side, the paper investigates whether the supply of ODA has been negatively affected by debt forgiveness and debt relief. The empirical question is whether and to what extent donors reduced their disbursement of ODA and grants following debt relief and debt forgiveness. In other words, does debt relief/forgiveness crowd out conventional external development financing? From the recipient side, the empirical question is whether and to what extent countries that have received debt relief/forgiveness subsequently received less ODA and other forms of concessional development financing. The advantage of the analysis from both the donor and recipient sides is that it presents a thorough view of the interactions between debt relief/forgiveness and conventional development financing by examining both the supply and the allocation of development finance.

First, the paper examines the trend of the flows of development financing by focusing on the post-1988 period for the effects of debt forgiveness and the 1997-2000 period for the impact of the HIPC Initiative. Second, the study undertakes a series econometric tests to examine the impact of debt relief and debt forgiveness on the flows of development assistance from both the donor side and the recipient side.

The econometric results indicate that the supply of ODA declined in 1998-2000, coinciding with the implementation of the HIPC Initiative. However, this downward trend had started prior to 1996. Nonetheless, analysis from the recipient side indicates that countries that received debt relief also received more ODA compared to those that did not qualify for debt relief. The results suggest that the behaviour of donors was not negatively affected by debt relief in terms of the total volume of ODA disbursements. The econometric results also indicate that the debt forgiveness initiatives undertaken especially since the 1988 'Toronto terms' did not crowd out conventional ODA. While the disbursement of ODA declined in this period, econometric analysis fails to establish a direct causal relationship between this downward trend of ODA and debt forgiveness, both in terms of the supply of ODA (on the donor side) and its allocation (on the recipient side).

The rest of the paper is organized as follows. The next section provides a brief history of the debt relief initiative. The third section examines the trend of the supply of ODA and other external development resources. The section highlights differences between countries that have received debt relief and those that have not reached a decision point. Section four presents the econometric methodology and discusses the empirical results. Section five concludes with a summary of the findings and a discussion of some policy implications.

2 See Daseking and Powell (1999), Easterly (1999), and Evans (1999) for an overview of the history of and issues related to debt forgiveness and debt relief. 


\section{Debt relief: a brief history}

\subsection{The debt build up and the debt crisis}

During the decades of the 1970s and 1980s, developing countries experienced an unprecedented accumulation of external debt, which eventually resulted in a debt crisis in the mid-1980s. The debt buildup can be attributed to several factors, which can be categorized into push factors, pull factors, and external shocks. Push factors included the excess supply of dollars resulting from the oil revenue booms of the 1970s, which caused a rush to lending by oil exporters and their banks in the west as they sought to get rid of the excess liquidity. This forced lending was also motivated by economic interests of the creditor countries seeking to stimulate exports and protect their domestic industry and employment. Push factors also included strategic and political motivations for lending aimed at supporting client regimes in the third world in order to counteract the expansion of rival superpowers. ${ }^{3}$

Pull factors of the debt buildup included the need of developing countries to borrow in order to finance development programmes in the post-independence era. Further borrowing was necessitated by the need for funds to maintain development projects originally financed by borrowing. External borrowing also led to further borrowing especially in countries led by corrupt and inept regimes that squandered borrowed funds through embezzlement and capital flight. There is substantial evidence in the literature that suggests a vicious cycle of borrowing leading to capital flight, which leads to further borrowing (Boyce 1992, 1993; Ndikumana and Boyce 2002). Furthermore, the myopic attitude of some government led to accumulation of debt as these government discounted heavily the adverse effects of debt on future regimes and future generations (Easterly 1999; Alesina and Tabellini 1989).

In addition to push and pull factors, a number of adverse external shocks also accentuated the accumulation of external debt by weakening the fiscal situation and the balance of payments. These include terms of trade shocks, world recessions that reduced the demand for third world products, and droughts and political crises. The dependence on a narrow range of export products also contributed to the vulnerability of the debtor countries to external shocks.

\subsection{Non-concessional flow rescheduling}

In the early 1980s, it became clear that developing countries could not sustain their debt burden and most of them faced insolvency problems. As a result, private creditors reduced lending to limit their exposure. Official creditors responded by adopting nonconcessional flow rescheduling while bilateral agencies provided new lending aimed at supporting adjustment programmes. Non-concessional flow rescheduling consists of an agreement between Paris Club creditors and debtor countries whereby the former accepts the delaying of the receipt of payments falling due and a rescheduling of these payments over a given period.

3 Ndikumana and Boyce (1998) discuss evidence of politically motivated lending by the United States and international financial institutions to the former Zaire under the client regime of Mobutu. External borrowing was used to finance massive capital flight and left the country heavily indebted. 
Non-concessional flow rescheduling produced important benefits for debtors and creditors. The process resulted in a reduction of annual debt service payments, allowing debtors to finance adjustment programmes and reducing pressure on government budgets. For creditors, flow rescheduling took away the pressure and need for disbursing new direct development finance and proved to be less costly both financially and politically.

Non-concessional flow rescheduling, however, had important negative effects on debtors. Flow rescheduling leaves the present value of debt unchanged, which implies no accounting loss for the creditor. In contrast, the process implies an increase in the stock of debt over time. By the end of the 1980s, it was clear that non-concessional flow rescheduling was causing debt overhang by accelerating the debt buildup, making the debt burden unsustainable for many countries. ${ }^{4}$ New strategies for addressing the debt crisis were called for in order to reduce the debt burden instead of simply delaying debt payments.

\subsection{Debt forgiveness and debt relief under the HIPC Initiative}

A concerted effort of reducing the debt burden for developing countries was initiated in April 1987 following a proposition by Nigel Lawson, Chancellor of the Exchequer of the United Kingdom, who suggested that debt rescheduling by Paris Club creditors should be at below market rates of interest. This was an important step beyond nonconcessional flow rescheduling as the proposed new strategy was explicitly aimed at reducing the present value of debt outstanding. However, the major Paris Club creditors could not agree on specific mechanisms for reducing the debt. Three propositions were advanced. The United Kingdom proposed a reduction of the interest rate charged on rescheduled loans. France proposed a reduction of the payments falling due by a half while rescheduling the remainder of the debts at the appropriate market rate. The United States opposed any reduction of the present value of debt and agreed only on increasing the grace period without any accounting loss to creditors. At the Toronto G-7 summit in 1988 , a compromise was reached, giving creditors a menu of the three options in what came to be known as the 'Toronto terms'.

Under the Toronto terms, 28 reschedulings were undertaken for 20 countries for an estimated total of about US\$ 6 billion (Daseking and Powell 1999). Despite this effort, however, the stock of debt continued to accumulate and it became clear that more needed to be done. In 1990, the United Kingdom proposed more aggressive measures including a reduction of the present value of debt by 67 per cent. However, in 1991, the Paris Club agreed to raise the degree of concessionality to only 50 per cent under what became known as the 'London terms'. The degree of concessionality was raised to 67 per cent in Naples at the 1994 Paris Club summit under the 'Naples terms'.

4 Debt sustainability is gauged using various indicators of indebtedness (net present value of debt and debt service) and the country's ability to pay (exports revenue, national income, and government revenue). For example, the thresholds for debt sustainability were set to 200-250 per cent for the net present value of debt to exports ratio and 20-25 per cent for the total debt service to exports ratio under the original HIPC Initiative. The thresholds were reduced to 150 per cent and 15-20 per cent, respectively, under the enhanced HIPC Initiative. 
The debt forgiveness process that started in 1988 has gained some momentum over the last decade. However, traditional debt forgiveness remains insufficient to alleviate the debt problems of low-income countries. In contrast, the process implies very low costs for the donors; the amount of debt forgiven represents a tiny fraction of the donors' gross national incomes, generally less than 1 per cent (Development Assistance Committee).

In an attempt to link debt forgiveness directly to poverty reduction, the World Bank in conjunction with the IMF and other members of the donor community launched in 1996 a global response to the debt crisis, known as the HIPC Initiative. The objective of the programme is to 'eliminate debt as an obstacle to poverty reduction' (Wolfenson 2001). As of September 2002, 27 HIPCs had reached the decision point, receiving a total of US\$ 41.5 billion in debt service relief (Appendix Table).

However, the HIPC Initiative continues to face several challenges. On the debtor side, the speed of implementation of the required conditions for meeting the decision point is slower than expected due to delays in the preparation and implementation of poverty reduction strategy papers (PRSP) and delays in completion of poverty reduction growth facility (PRGF) reviews (see Development Committee 2002). The situation in conflictridden countries poses a special challenge for meeting the criteria for debt relief as they struggle to make the expected progress in achieving peace while their economies are devastated by war.

On the creditor side, the main constraints are the slow speed in reaching agreements with HIPCs and the delays in the actual delivery of debt relief (Development Committee 2002). The delays in delivery by regional entities such as regional development banks and the European Union are especially problematic given that they contribute a large share of multilateral lending. Moreover, several multilateral creditors and non-Paris club creditors have not yet approved debt relief for any HIPCs. The efforts by the World Bank and the IMF to increase creditor participation have been typically limited to moral suasion and mediation between HIPCs and creditors. It is clear that a more aggressive strategy is needed to accelerate the process of debt relief by enrolling all the creditors.

\section{Additionality of debt relief: highlights from the data}

The objective of the debt relief initiative is to allow poor countries to achieve higher economic growth through availability of a larger volume of finance. To achieve this objective, debt relief must be given in addition to - not as a substitute for-conventional development aid, grants, and other concessional external loans. The first set of evidence in this section consists of highlights from the data on the supply of ODA and grants by major donor countries. The focus is on the debt forgiveness period (1989-2000) and the debt relief period (1998-2000). Second, the section examines recipient data on the allocation of ODA, grants, and development financing among developing countries. The objective is to assess whether and to what extent countries that have received debt relief/forgiveness received lower volumes of non-debt generating finance and concessional lending during the debt relief/forgiveness period and compared to other developing countries that have received less or no debt relief/forgiveness. 


\subsection{Official development aid}

The data indicate that the volume of official development aid flows to developing countries as a group has declined since the 1990s. For example, aid to Sub-Saharan African countries declined from US\$ 17,906 in 1990 to US\$13,453 in 2000 or from US\$ 34 to US\$ 20 per capita (World Development Indicators 1997 and 2002). Figure 1 illustrates this negative trend of the supply of ODA for HIPCs. This trend raises concerns with regard to the effectiveness of the debt relief initiative. Without substantial volumes of aid and concenssional lending, it is impossible for low-income countries to raise domestic savings and investment and overcome aid dependence and poverty.

Figure 1

Total supply of ODA and grants by 17 major donors

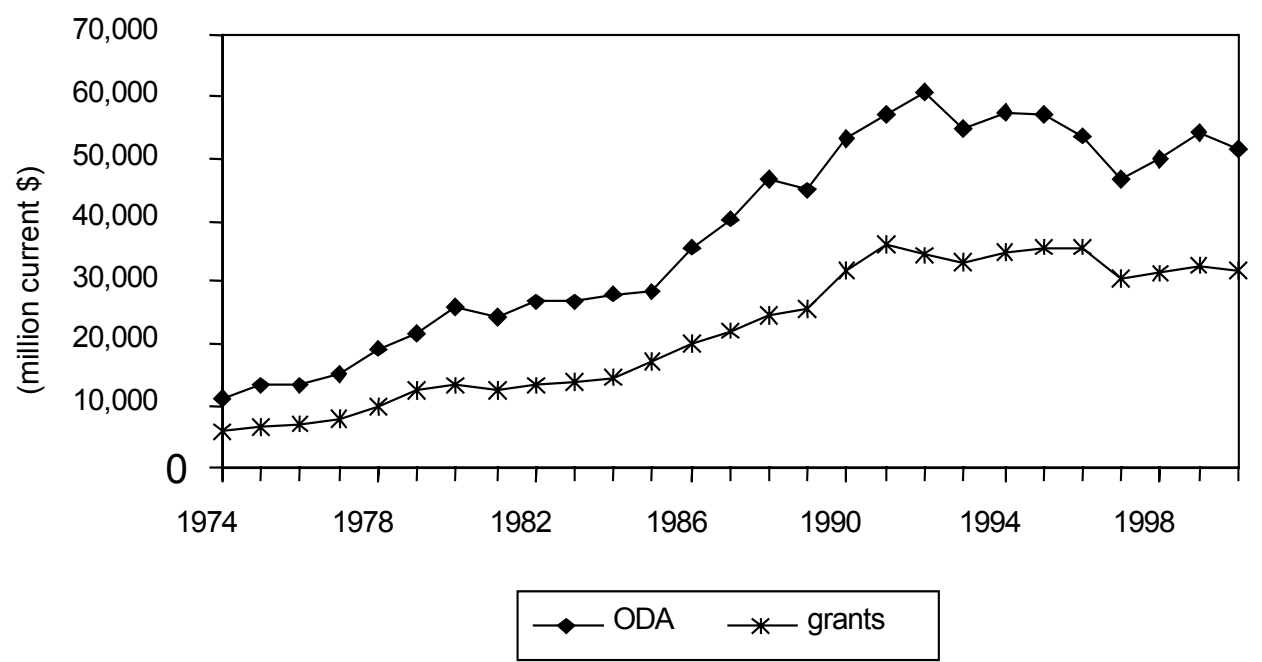

Figure 2

Aid per capita to HIPCs (population-weighted averages), 1970-2000

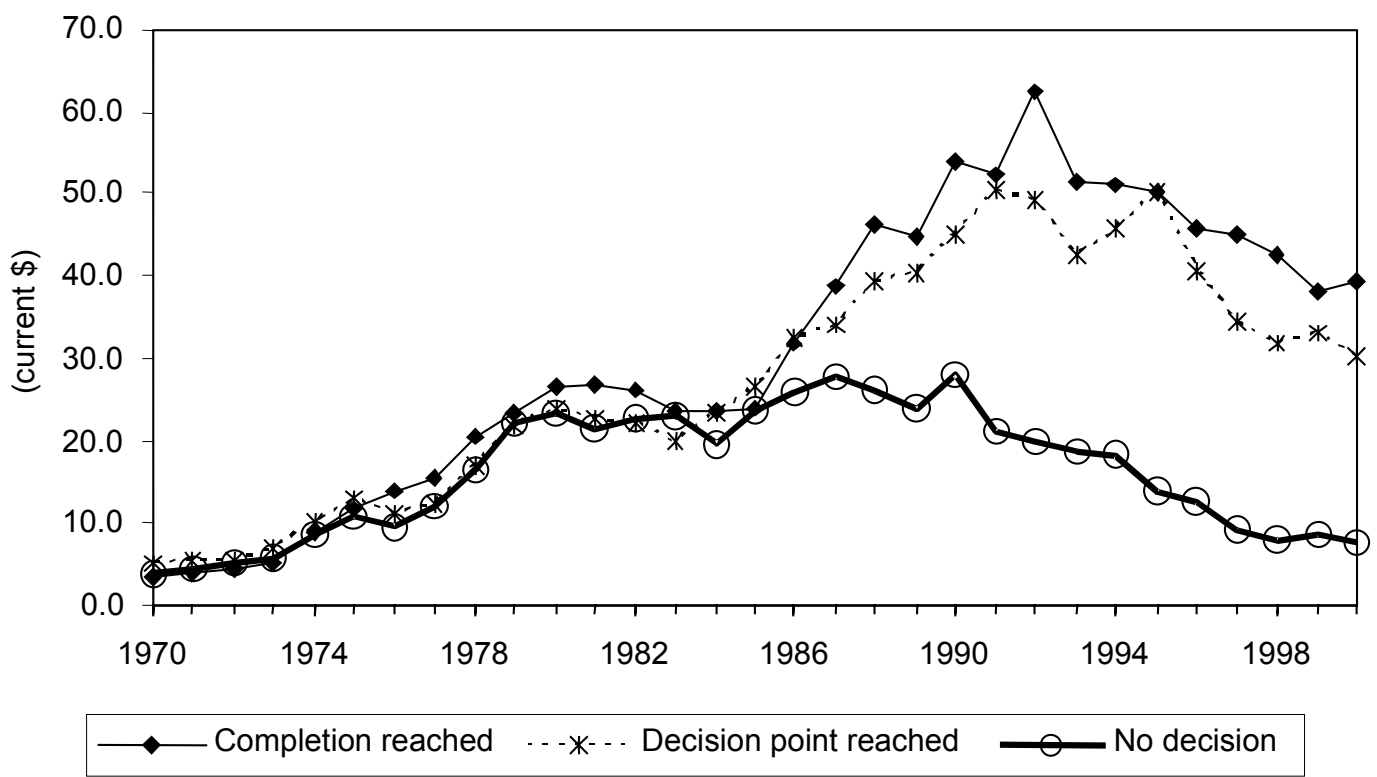


Table 1

Aid per capita to HIPCs before and during debt forgiveness period (US\$, average per period)

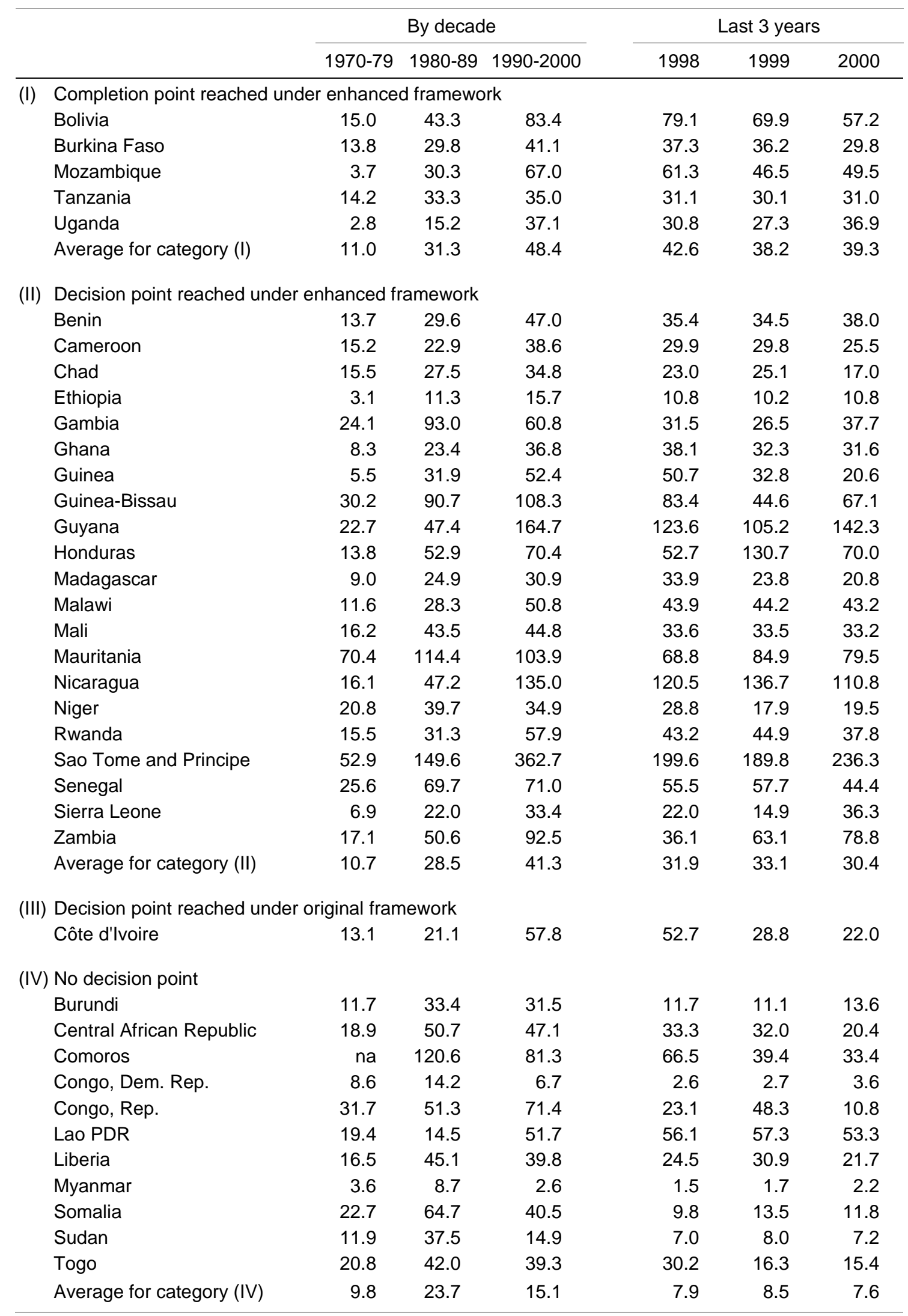

Source: Author's calculations from World Development Indicators 2002. 
Among HIPCs, the decline in aid flows in the 1990s is particularly pronounced among those that have not yet reached a decision point (Table 1 and Figure 2). In this group, average aid per capita declined from US\$ 24 in the 1980s to US\$ 15 in the 1990s. Aid per capita in 2000 is lower than in 1998 in half of the HIPCs. Debt relief is not likely to be accompanied by a net increase in overall resources given the decline in aid and considering the fact that low-income countries are unable to attract substantial volumes of alternative external resources such as private capital flows.

\subsection{Net transfers on debt and net flows of resources}

Debt relief is expected to be followed by an increase in net inflows of external resources due to a reduction in debt service payments. However, net transfers on debt for HIPCs have declined steadily even during the debt rescheduling period after 1988 (Figure 3). For many HIPCs, net transfer on debt is negative for several years.

The financial situation of HIPCs is even more precarious if we examine all the capital accounts by taking into account all capital inflows and outflows. First, these countries receive little private capital inflows, partly due to high investment risk. 5 Second, these countries also experience high levels of capital flight. Several studies indicate that a large amount of capital continues to flee even from the countries referred to as severely indebted low-income countries (SILIC). Boyce and Ndikumana (2001) find that the group of SILICs in Sub-Saharan Africa is a 'net creditor' to the rest of the world in the sense that the amount of accumulated capital flight exceeds the stock of debt owed by this group as a whole. Moreover, Ndikumana and Boyce (2002) find that a large fraction of the capital flight from SSA is financed by external borrowing, a

Net transfers on debt for HIPCs (weighted average, \% of total debt)

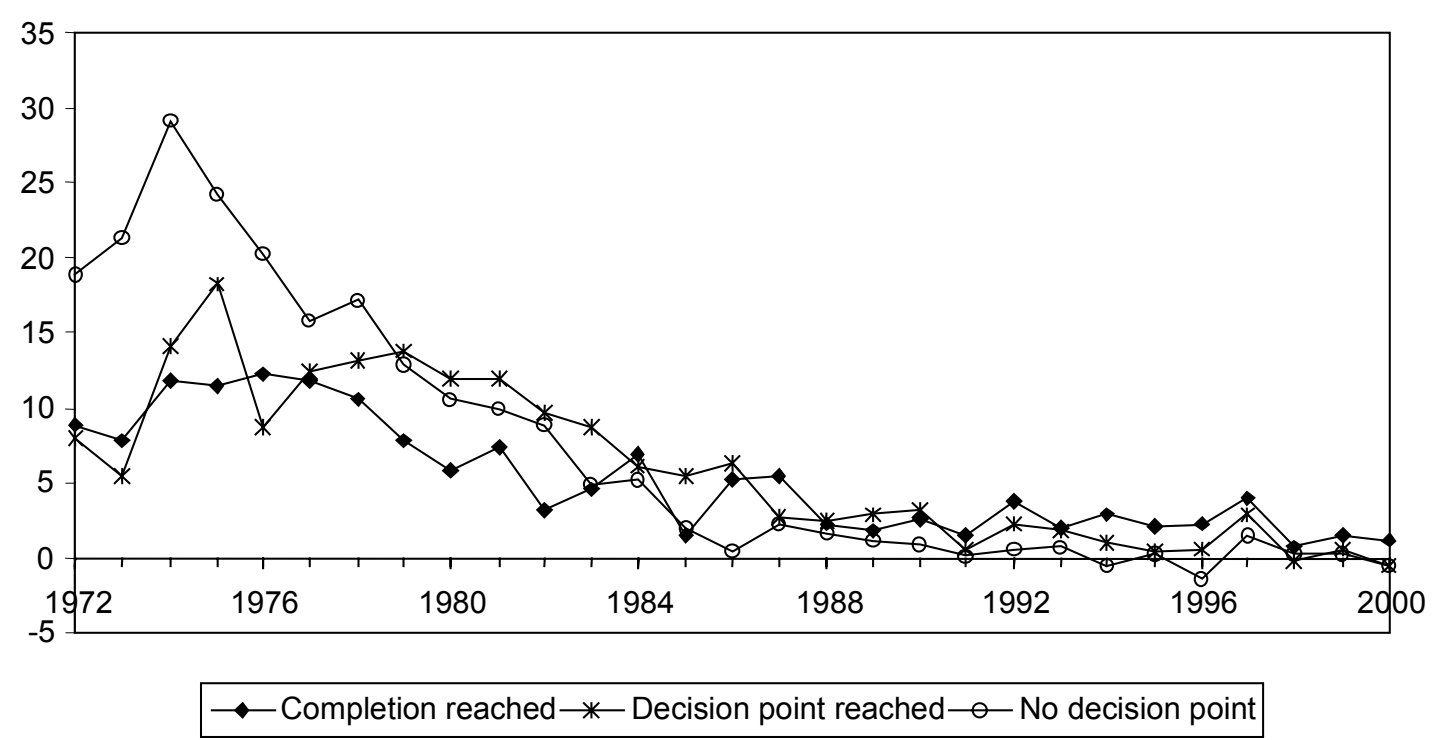

5 See Ndikumana (2002) for a discussion of private capital flows to Sub-Saharan Africa. 
phenomenon referred to as 'debt-fuelled' capital flight (see also Boyce 1993). 6 The authors find that, on average, out of every dollar borrowed from abroad, as much as 70 cents are channelled back abroad as capital flight. Ndikumana and Boyce also find that there is a tendency for capital flight to persist, possibly arising from habit formation and contagion effects.

The evidence of a two-way causal relationship between external borrowing and capital flight has important policy implications for debt relief and debt management (see Ndikumana and Boyce 2002 for a detailed discussion). The phenomenon of debt-fuelled capital flight implies a significant degree of responsibility on the part of creditors. Knowingly or unknowingly, creditors continued to finance the export of private capital from developing countries instead of financing development projects. For political and strategic reasons, bilateral creditors often chose to continue disbursing loans despite the existence of clear evidence of embezzlement of the borrowed funds (see Ndikumana and Boyce 1998). The implication is that official lenders should share the responsibility for the debt burden and the cost of debt-fuelled capital flight.

In such circumstances, debt relief should be seen not as a privilege for HIPCs but, to some extent, as an obligation on the part of creditors. First, the latter have a moral obligation to alleviate the adverse effects of external debt since part of the debt was politically motivated. Second, it is morally questionable to put the burden of debt service on the new regimes of debtor countries and their populations given that they were not involved in making the borrowing decisions and that they did not benefit much from the borrowed funds that were squandered by past rulers.

\section{Econometric tests of additionality of debt relief and debt forgiveness}

The econometric tests of additionality aim at investigating whether there is a negative relation between debt relief or debt forgiveness on the one hand and the disbursement of external development financing on the other hand. A negative relation implies crowding out of external official development financing by debt relief and debt forgiveness.

\subsection{Tests for additionality from the donor side}

\subsubsection{Data and methodology}

The analysis is based on data for 22 donors for the period 1980-2000. The 1980 cut-off point gives a maximum number of countries with consistent data on the relevant variables. The complete sample includes Australia, Austria, Belgium, Canada, Denmark, Finland, France, Germany, Greece, Ireland, Italy, Japan, Luxembourg, Netherlands, New Zealand, Norway, Portugal, Spain, Sweden, Switzerland, United Kingdom, and United States. However some countries are excluded from the regressions due to missing data. Greece is excluded from all regressions due to missing data on ODA and debt forgiveness.

6 Also see Ndikumana and Boyce (1998) for a case study of the links between external borrowing and capital flight from former Zaire (renamed Democratic Republic of Congo in 1997) under the Mobutu regime. 


\subsubsection{Tests for additionality of debt relief}

The first set of regressions is panel data and cross-sectional regressions over the period 1998-2000 relating the disbursement of ODA to the supply of debt relief under the HIPC Initiative (Table 2, columns 1 and 2). To check for robustness of the coefficients, alternative estimation methods are used: panel-data OLS, fixed-effects (or within) estimation, and random-effects estimation. The results of regressions with fixed effects and random effects are similar and only the OLS and random-effects estimates are reported.

The second set of tests consists of regressions over the period 1980-2000 including a dummy for the HIPC Initiative period 1998-2000 (Table 2, columns 3 and 4). These regressions aim at examining the question of whether and to what extent the supply of ODA was affected negatively by the implementation of the HIPC Initiative.

\subsubsection{Tests for additionality of debt forgiveness}

The test of additionality of debt forgiveness is based on panel data regressions over the 'post-Toronto' period 1989-2000 relating the disbursement of ODA to the volume of debt forgiveness supplied by donors (Table 3 ).

\subsubsection{Model specification}

Given that there is no clear-cut theoretical basis for the specification of the model relating the supply of official development financing to debt relief/forgiveness, the regression equation in this study is built up by including potential regressors one by one and discarding the ones that are systematically insignificant. However, debt relief and debt forgiveness are retained regardless of statistical significance given that they are the focus of the investigation. The following explanatory variables were explored:

Indicators of the capacity to supply ODA: per capita GDP, government consumption (per cent of GDP), the current account balance (per cent of GDP), the fiscal budget balance (per cent of GDP), and total exports (per cent of GDP). It is expected that a higher per capita income, current account surplus, budget surplus, and exports are positively related to the volume of debt relief/forgiveness. These indicators are measures of the availability of resources to finance debt relief/forgiveness. Government consumption, as a proxy of total government spending also is expected to be positively related to debt relief/forgiveness. 7 All things equal, governments with larger budgets theoretically also have a higher capacity to absorb higher volumes of debt forgiveness.

Indicators of the 'interest' of donor countries in the developing world: arms exports as per cent of total exports, arms imports as a percentage of total imports, net foreign direct investment (per cent of GDP), and a dummy indicating whether the donor country was a former colonizer. We would expect these indicators to be positively related to debt relief/forgiveness. The decision to give debt relief/forgiveness is not entirely altruistic. Donors often use development assistance to pursue their own political and strategic goals. Empirical evidence shows that various donors behave differently but that in general, aid giving is influenced by political alliances and colonial history (Alesina and

7 Government consumption is preferred to total government expenditures in this analysis because the former is better reported (less missing observations). 
Dollar 2000) and other donor-specific considerations under the headings of 'moral vision' (Lumsdaine 1993) or broad 'strategic interests' (Maizels and Nissanke 1984). 8

Indicators of the donor's political regime: a dummy indicating whether 'the dominant party in the legislative arm is of right-wing ideology'. The dummy equals if the dominant party in the legislative arm of the government is of left wing or centre ideology and 1 if it is of right-wing ideology. It is expected that right-wing governments would be less inclined to forgive debt than left-wing governments.

The following explanatory variables are retained: per capita GDP, government consumption, the current account balance, the 'right-wing' regime dummy, and the colonial history dummy. In addition to these observed explanatory factors, the model also accounts for unobserved country specific effects. The model can be summarized as follows:

$$
\text { For debt relief: } O D A_{i t}^{D}=\alpha_{1} R E L I E F_{i, t-1}+\mathbf{X}_{i, t-1} \boldsymbol{\beta}+v_{i}+\varepsilon_{i t}
$$

$$
\text { For debt forgiveness: } O D A_{i t}^{D}=\beta_{1} F O R G I V_{i, t-1}+\mathbf{X}_{i, t-1} \boldsymbol{\delta}+v_{i}+\varepsilon_{i t}
$$

where $O D A_{i t}^{D}$ is the disbursement of ODA by the donor $i$ in year $t$ as a percentage of the donor's GDP, RELIEF is debt relief and FORGIV is debt forgiven by the donor as percentage of the donor's GDP, $\mathbf{X}$ is a vector of the explanatory factors described above, $v_{i}$ represents country specific effects, and $\varepsilon$ is a white-noise error term. An alternative specification where FORGIV is entered contemporaneously yields similar results as when its lag is used and a Hausman test for endogeneity indicates that the differences between the coefficients in the two specifications are not systematic. ${ }^{9}$ In this study the lagged values of debt forgiveness are used, which allows us to examine whether current debt forgiveness crowds out future aid flows.

\subsection{Regression results for debt relief}

The results of regressions relating ODA to the volume of debt relief using OLS and random-effects estimation methods suggest that the supply of debt relief has no statistically significant effect on the disbursement of ODA (Table 2, columns 1 and 2). These results suggest that donors that supplied more debt relief did not disburse less ODA. There is, therefore, no statistical evidence of crowding out of ODA by debt relief.

The regression results with a time dummy for the HIPC Initiative period $(=1$ for 1998-2000) indicate that the supply of ODA was lower during this period (Table 2 ,

8 There is no consensus in the empirical literature on the links between creditors' political interests and debt forgiveness. For example, Neumayer (2002) finds that except for the United States military interests, measures of creditors' political interests affect neither the decision to forgive debt nor the volume of debt forgiven.

9 Using the model including debt forgiveness, log of per capita income, government consumption and the current account surplus, the Hausman test yields a t-statistic of 1.35 with a p-value of 0.93 when the random-effects method is used and 1.8 with a p-value of 0.77 when the OLS method is used. 
columns 3 and 4). This result is consistent with the evidence in Figure 1 that indicates a decline in ODA in the 1990s. These econometric results suggest that while the disbursement of ODA by donors declined at the end of the 1990s, there is no statistical support for a direct causal relationship between this decline in ODA and the volume of debt relief supplied by donors.

Table 2

Impact of debt relief under the HIPC Initiative on the supply of ODA

\begin{tabular}{|c|c|c|c|c|}
\hline \multirow[b]{2}{*}{$\begin{array}{l}\text { Explanatory variables: lagged one year } \\
\text { (except for dummies) }\end{array}$} & \multicolumn{2}{|c|}{$\begin{array}{l}\text { 1998-2000: } \\
\text { with volume of debt relief }\end{array}$} & \multicolumn{2}{|c|}{$\begin{array}{l}\text { 1980-2000: } \\
\text { with HIPC period dummy }\end{array}$} \\
\hline & $\begin{array}{l}(1) \\
\text { OLS }\end{array}$ & $\begin{array}{c}(2) \\
\text { Random-effects (a }\end{array}$ & $\begin{array}{l}(3) \\
\text { OLS }\end{array}$ & $\begin{array}{c}(4) \\
\text { Random-effects }\end{array}$ \\
\hline Debt relief (\% of GDP) & $\begin{array}{l}4.241 \\
(1.0)\end{array}$ & $\begin{array}{l}0.087 \\
(0.1)\end{array}$ & & \\
\hline HIPC dummy (=1 for 1998-2000) & & & $\begin{array}{l}-0.060 \\
(-2.7)\end{array}$ & $\begin{array}{l}-0.050 \\
(-4.1)\end{array}$ \\
\hline Log per capita GDP & $\begin{array}{l}0.297 \\
(3.7)\end{array}$ & $\begin{array}{l}0.295 \\
(3.4)\end{array}$ & $\begin{array}{l}0.209 \\
(10.1)\end{array}$ & $\begin{array}{l}0.131 \\
(4.1)\end{array}$ \\
\hline Government consumption (\% of GDP) & $\begin{array}{l}0.041 \\
(7.3)\end{array}$ & $\begin{array}{l}0.033 \\
(3.9)\end{array}$ & $\begin{array}{c}0.044 \\
(29.0)\end{array}$ & $\begin{array}{l}0.021 \\
(7.8)\end{array}$ \\
\hline Current account balance (\% of GDP) & $\begin{array}{l}0.0011 \\
(0.2)\end{array}$ & $\begin{array}{l}0.003 \\
(0.9)\end{array}$ & $\begin{array}{l}0.006 \\
(2.3)\end{array}$ & $\begin{array}{l}-0.002 \\
(-1.6)\end{array}$ \\
\hline Observations & 63 & 63 & 423 & 423 \\
\hline $\mathrm{R}^{2}$ & 0.59 & & 0.64 & \\
\hline Within $\mathrm{R}^{2}$ & & 0.05 & & 0.15 \\
\hline Between $\mathrm{R}^{2}$ & & 0.58 & & 0.69 \\
\hline Overall $R^{2}$ & & 0.57 & & 0.62 \\
\hline $\mathrm{F}(\mathrm{H} 0$ : all coefficients $=0)$ & $\begin{array}{l}19.0 \\
(0.00)\end{array}$ & & $\begin{array}{l}267.4 \\
(0.00)\end{array}$ & \\
\hline Chi2 for model (Prob>Chi2) & & $\begin{array}{l}26.1 \\
(0.00)\end{array}$ & & $\begin{array}{l}96.6 \\
(0.00)\end{array}$ \\
\hline Chi2 for Hausman test (Prob>Chi2) ${ }^{(a}$ & & $\begin{array}{l}1.08 \\
(0.9)\end{array}$ & & $\begin{array}{l}19.12 \\
(0.00)\end{array}$ \\
\hline
\end{tabular}

Note: The dependent variable is official development aid or grants disbursed by DAC. Coefficient on the constant term not reported for reason of space. The t-statistics (for OLS) and z-statistics (for random-effects regressions) are given in parenthesis. Fixed-effects estimates not reported: the Hausman test fails to reject the null hypothesis that the differences in fixed-effects and randomeffects coefficients are systematic (Chi2=1.08 with a $p$-value of 0.89 ).

(a Hausman test of random versus fixed effects specification: $\mathrm{HO}=$ difference in coefficients not systematic.

\subsection{Regression results for debt forgiveness}

The regression results show no effect of debt forgiveness on the supply of ODA (Table 3). The coefficient on debt forgiveness is statistically insignificant and this result holds when alternative estimation methods are used (the OLS, fixed-effects, and random-effects methods). The results suggest that the debt forgiveness process initiated in 1988 did not have any direct effects on the volume of ODA disbursed by donors. 
Table 3

Supply of ODA and debt forgiveness (1989-2000)

\begin{tabular}{|c|c|c|c|}
\hline $\begin{array}{l}\text { Explanatory variables: lagged one year } \\
\text { (except for dummies) }\end{array}$ & $\begin{array}{l}(1) \\
\text { OLS }\end{array}$ & $\begin{array}{c}(2) \\
\text { Fixed-effects }\end{array}$ & $\begin{array}{c}\text { (3) } \\
\text { Random-effects }\end{array}$ \\
\hline Debt forgiven (\% GDP) & $\begin{array}{l}0.031 \\
(0.07)\end{array}$ & $\begin{array}{l}-0.221 \\
(-0.9)\end{array}$ & $\begin{array}{l}-0.266 \\
(-0.9)\end{array}$ \\
\hline Log per capita GDP & $\begin{array}{l}0.136 \\
(3.9)\end{array}$ & $\begin{array}{l}-0.086 \\
(-1.5)\end{array}$ & $\begin{array}{l}0.182 \\
(2.5)\end{array}$ \\
\hline Government consumption (\% of GDP) & $\begin{array}{l}0.049 \\
(17.7)\end{array}$ & $\begin{array}{l}0.0003 \\
(0.1)\end{array}$ & $\begin{array}{l}0.013 \\
(2.5)\end{array}$ \\
\hline Current account balance ( $\%$ of GDP) & $\begin{array}{l}0.011 \\
(2.6)\end{array}$ & $\begin{array}{l}-0.014 \\
(-6.8)\end{array}$ & $\begin{array}{l}-0.012 \\
(-4.1)\end{array}$ \\
\hline Right-wing legislative branch dummy & $\begin{array}{l}-0.019 \\
(0.9)\end{array}$ & & $\begin{array}{l}0.006 \\
(0.4)\end{array}$ \\
\hline Former colonizer dummy & $\begin{array}{l}-0.084 \\
(-4.4)\end{array}$ & & $\begin{array}{l}-0.092 \\
(-1.3)\end{array}$ \\
\hline Observations & 181 & & 181 \\
\hline $\mathrm{R}^{2}$ & 0.67 & & \\
\hline Within $\mathrm{R}^{2}$ & & 0.19 & 0.08 \\
\hline Between $\mathrm{R}^{2}$ & & 0.20 & 0.39 \\
\hline Overall $\mathrm{R}^{2}$ & & 0.12 & 0.37 \\
\hline F (H0: all coefficients $=0)$ & $\begin{array}{l}73.9 \\
(0.000)\end{array}$ & $\begin{array}{l}13.4 \\
(0.000)\end{array}$ & \\
\hline Chi2 for model (Prob>Chi2) & & & $\begin{array}{l}29.9 \\
(0.000)\end{array}$ \\
\hline Chi2 for Hausman test (Prob>Chi2) ${ }^{(a}$ & & & $\begin{array}{l}60.6 \\
(0.000)\end{array}$ \\
\hline
\end{tabular}

Notes: The dependent variable is official development aid disbursed by DAC (\% of GDP). The coefficient on the constant term is not reported for reason of space. The t-statistics are given in parenthesis.

(a Hausman test of random vs. fixed effects specification: $\mathrm{H} 0=$ difference in coefficients not systematic.

\subsection{Tests for additionality from the recipient side}

\subsubsection{Data and methodology}

This section examines the links between debt relief and debt forgiveness on the one hand and the inflows of external development financing in developing countries on the other hand. This study focuses on official development aid and concessional loans. The analysis is based on a sample of 111 developing countries for the period 1989-2000. However, the number of countries included in the regressions varies depending on data availability.

The analysis from the recipient side investigates the question of whether and to what extent low-income countries received less conventional development financing following debt relief and debt forgiveness. This analysis supplements the analysis from the donor side by examining the allocation of external development financing among aid recipients. 


\subsubsection{Tests for additionality of debt relief}

The tests for additionality of debt relief focus on the 1997-2000 period during which countries started receiving debt relief under the HIPC Initiative. The analysis is based on cross-sectional regressions including the volume of debt relief received (Table 4, columns 1 and 2) or a dummy indicating whether a country received debt relief by the end of the year 2000 (Table 4, columns 3 and 4). The analysis is based on the following empirical equation:

$$
\operatorname{EXTFIN~}_{j}^{R}=\alpha_{0}+\alpha_{1} R E L I E F_{j}+\mathbf{Z}_{j} \gamma+\varepsilon_{i}
$$

where $\operatorname{EXTFIN}_{j}^{R}$ is a measure of external financing received by the developing country, specifically ODA, as a percentage of gross national income and concessional loans as a percentage of total debt. The vector $\mathbf{Z}$ includes two categories of factors. 10 The first category includes indicators of the recipient's need for debt relief: per capita income, the debt to GNP ratio, and the debt service to exports ratio. It is expected that countries with lower income and higher indebtedness will benefit from more debt relief. The second category of factors includes indicators of the macroeconomic policy environment and the political climate. It is expected that countries that have established a record of sound macroeconomic policy and a stable political environment will receive more debt relief. The macroeconomic policy stance is proxied by the inflation rate while the political environment is proxied by an index of political freedom combining indexes of political rights and civil liberty from Freedom House. 11 RELIEF is alternatively the volume of debt relief received by a country (per cent of gross national income in ODA regressions and per cent of total debt in regressions for concessional loans) or a dummy for debt relief that equals 1 if the country received debt relief under the HIPC Initiative by December 2000 and 0 otherwise.

\subsubsection{Tests for additionality of debt forgiveness}

The tests for additionality of debt forgiveness cover the 1989-2000 period where developing countries received debt forgiveness under the various debt alleviation schemes starting from the 1988 'Toronto terms'. The analysis is based on the following empirical equation:

$$
\operatorname{EXTFIN~}_{j t}^{R}=\alpha_{1} \text { FORGIVE }_{j, t-1}+\mathbf{Z}_{j, t-1} \boldsymbol{\beta}+\eta_{j}+\varepsilon_{j t}
$$

where $\operatorname{EXTFIN~}_{j}^{R}$ is ODA (per cent of gross national income) and concessional loans (per cent of total debt), FORGIVE is debt forgiveness received by the country (per cent of gross national income or per cent of total debt), vector $\mathbf{Z}$ includes the same factors as

10 See Neumayer (2002) for a detailed empirical analysis of the determinants of the allocation of debt forgiveness.

11 The freedom index (FREEDOM) is computed as: FREEDOM $=14$ - political rights - civil liberty. The indexes of political rights and civil liberty range from 1 (best) to 7 (worst). With this transformation, a higher value of the freedom index corresponds to a better political environment, which makes it easier to interpret the regression coefficients on the FREEDOM variable. 
in equation (3), $\eta_{j}$ represents country-specific effects, and $\varepsilon$ is a white-noise error term. The equation is estimated using OLS, fixed-effects, and random-effects estimation methods.

\subsection{Regression results for additionality of debt relief}

The cross-sectional regression results show a positive relationship between the volume of debt relief received on the one hand and the volume of ODA and concessional loans on the other hand (Table 4). The results indicate that countries that qualified for debt relief under the HIPC Initiative also received higher volumes of ODA and concessional loans during the 1997-2000 period. The regression coefficients on the volume of debt relief suggest that recipients of debt relief received about 9.6 cents of ODA and 23.8 cents of concessional loans in addition to each dollar of debt relief received. This implies that these countries experienced a net increase in new external resources.

Table 4

Debt relief and development aid:

cross-sectional regressions with recipient data, 1997-2000

\begin{tabular}{|c|c|c|c|c|}
\hline & \multicolumn{2}{|c|}{$\begin{array}{c}\text { Regression with volume } \\
\text { of debt relief }\end{array}$} & \multicolumn{2}{|c|}{$\begin{array}{l}\text { Regressions with HIPC dummy } \\
(=1 \text { if reached decision point })\end{array}$} \\
\hline & $\begin{array}{c}(1) \\
\text { Aid/GNP }\end{array}$ & $\begin{array}{c}(2) \\
\text { Concessional } \\
\text { loans/debt }\end{array}$ & $\begin{array}{c}(3) \\
\text { Aid/GNP }\end{array}$ & $\begin{array}{c}(4) \\
\text { Concessional } \\
\text { loans/debt }\end{array}$ \\
\hline Debt relief (a & $\begin{array}{l}0.0962 \\
(9.0)\end{array}$ & $\begin{array}{l}0.238 \\
(1.9)\end{array}$ & & \\
\hline Debt relief dummy & & & $\begin{array}{l}5.567 \\
(3.4)\end{array}$ & $\begin{array}{l}10.465 \\
(1.9)\end{array}$ \\
\hline $\log \left(\right.$ income $_{1996}$ ) & $\begin{array}{l}-3.192 \\
(-6.3)\end{array}$ & $\begin{array}{l}-20.765 \\
(-7.8)\end{array}$ & $\begin{array}{l}-3.045 \\
(-4.7)\end{array}$ & $\begin{array}{l}-21.360 \\
(-8.8)\end{array}$ \\
\hline EDT/GNP $_{1996}$ & $\begin{array}{l}0.001 \\
(0.2)\end{array}$ & $\begin{array}{l}-0.056 \\
(-1.8)\end{array}$ & $\begin{array}{l}0.034 \\
(2.7)\end{array}$ & $\begin{array}{l}-0.051 \\
(-1.7)\end{array}$ \\
\hline TDS/XGS ${ }_{1996}$ & $\begin{array}{l}-0.081 \\
(-2.5)\end{array}$ & $\begin{array}{l}-0.610 \\
(-3.0)\end{array}$ & $\begin{array}{l}0.035 \\
(-0.9)\end{array}$ & $\begin{array}{l}-0.560 \\
(-2.9)\end{array}$ \\
\hline $\mathrm{CPI}_{1996}$ & $\begin{array}{l}0.0005 \\
(1.0)\end{array}$ & $\begin{array}{l}-0.007 \\
(-2.0)\end{array}$ & $\begin{array}{l}-0.008 \\
(-1.0)\end{array}$ & $\begin{array}{l}-0.007 \\
(-2.1)\end{array}$ \\
\hline FREEDOM $_{1996}$ & $\begin{array}{l}0.351 \\
(1.9)\end{array}$ & $\begin{array}{l}0.726 \\
(0.9)\end{array}$ & $\begin{array}{l}0.561 \\
(2.7)\end{array}$ & $\begin{array}{l}0.857 \\
(1.1)\end{array}$ \\
\hline Observations & 104 & 104 & 104 & 104 \\
\hline $\mathrm{R} 2$ & 0.73 & 0.57 & 0.61 & 0.57 \\
\hline
\end{tabular}

Notes: $\quad\left({ }^{a}\right.$ Debt relief is scaled as the dependent variable: by GNP for aid regressions and debt stock for concessional loans regressions.

The dependent variable is indicated in the column headings: average aid/GNP and the ratio of concessional loans to total debt (averaged over the 1997-2000 period). The t-statistics are given in parenthesis. The constant term is not reported for reason of space. The debt relief dummy $=1$ if the country has reached a decision point under the HIPC Initiative as of December 2000. The 1996 subscript on the explanatory variables indicates the value of the variable for 1996 (before the regression sample), which alleviates simultaneity bias. 


\subsection{Regression results for additionality of debt forgiveness}

The regression results for the effects of debt forgiveness on ODA and concessional loans vary depending on the estimation method that is being used (Table 5). While the random-effects estimation results indicate a significant positive relation between debt forgiveness and ODA, the relation is not statistically under the fixed-effects and the OLS estimation methods. Note that the Hausman test rejects the hypothesis that the differences between the random-effects coefficients and the fixed-effects coefficients are not systematic. This implies that the hypothesis that the country-level effects are adequately modelled by a random-effects model is not supported by the data in this

Table 5

Effects of debt forgiveness on ODA and concessional loans Regressions with recipient data (1989-2000)

\begin{tabular}{|c|c|c|c|c|c|c|}
\hline \multirow[b]{2}{*}{$\begin{array}{l}\text { Explanatory variables: } \\
\text { lagged one year (except for } \\
\text { dummies) }\end{array}$} & \multicolumn{3}{|c|}{ ODA (\% of GNI) } & \multicolumn{3}{|c|}{ Concessional loans (\% of debt stock) } \\
\hline & $\begin{array}{l}(1) \\
\text { OLS }\end{array}$ & $\begin{array}{c}(2) \\
\text { Fixed effects }\end{array}$ & $\begin{array}{l}\text { (3) } \\
\text { Random } \\
\text { effects }\end{array}$ & $\begin{array}{l}\text { (4) } \\
\text { OLS }\end{array}$ & $\begin{array}{c}(5) \\
\text { Fixed effects }\end{array}$ & $\begin{array}{l}\text { (6) } \\
\text { Random } \\
\text { effects }\end{array}$ \\
\hline Debt forgiven $(a$ & $\begin{array}{l}0.064 \\
(1.3)\end{array}$ & $\begin{array}{l}0.034 \\
(1.5)\end{array}$ & $\begin{array}{l}0.049 \\
(2.3)\end{array}$ & $\begin{array}{l}-0.024 \\
(-0.3)\end{array}$ & $\begin{array}{l}0.0379 \\
(1.0)\end{array}$ & $\begin{array}{l}-0.033 \\
(-0.8)\end{array}$ \\
\hline Log per capita GDP & $\begin{array}{l}-4.795 \\
(-16.3)\end{array}$ & $\begin{array}{l}-5.776 \\
(-3.4)\end{array}$ & $\begin{array}{l}-4.696 \\
(-8.2)\end{array}$ & $\begin{array}{l}-20.555 \\
(-31.6)\end{array}$ & $\begin{array}{l}-5.888 \\
(-3.4)\end{array}$ & $\begin{array}{l}-15.526 \\
(-11.8)\end{array}$ \\
\hline Debt stock/GNP & $\begin{array}{l}0.045 \\
(8.3)\end{array}$ & $\begin{array}{l}0.021 \\
(4.7)\end{array}$ & $\begin{array}{l}0.028 \\
(7.4)\end{array}$ & $\begin{array}{l}-0.029 \\
(-3.9)\end{array}$ & $\begin{array}{l}0.020 \\
(4.6)\end{array}$ & $\begin{array}{l}-0.021 \\
(-4.5)\end{array}$ \\
\hline Debt service/exports & $\begin{array}{l}-0.009 \\
(-0.6)\end{array}$ & $\begin{array}{l}0.027 \\
(1.5)\end{array}$ & $\begin{array}{l}0.024 \\
(1.4)\end{array}$ & $\begin{array}{l}-0.464 \\
(-6.2)\end{array}$ & $\begin{array}{l}0.027 \\
(1.5)\end{array}$ & $\begin{array}{l}-0.035 \\
(-1.9)\end{array}$ \\
\hline Inflation (CPI) & $\begin{array}{l}-0.001 \\
(-3.7)\end{array}$ & $\begin{array}{l}0.0001 \\
(0.4)\end{array}$ & $\begin{array}{l}-0.0004 \\
(-0.2)\end{array}$ & $\begin{array}{l}-0.003 \\
(-4.5)\end{array}$ & $\begin{array}{l}0.0001 \\
(0.4)\end{array}$ & $\begin{array}{l}-0.0002 \\
(-0.8)\end{array}$ \\
\hline Freedom index & $\begin{array}{l}0.446 \\
(5.3)\end{array}$ & $\begin{array}{l}-0.048 \\
(-0.4)\end{array}$ & $\begin{array}{l}0.085 \\
(0.8)\end{array}$ & $\begin{array}{l}1.0100 \\
(4.0)\end{array}$ & $\begin{array}{l}-0.043 \\
(-0.4)\end{array}$ & $\begin{array}{l}0.216 \\
(1.7)\end{array}$ \\
\hline Observations & 1066 & 1066 & 1066 & 1068 & 1068 & 1068 \\
\hline $\mathrm{R}^{2}$ & 0.46 & & & 0.49 & & \\
\hline Within $\mathrm{R}^{2}$ & & 0.05 & 0.04 & & 0.05 & 0.06 \\
\hline Between $\mathrm{R}^{2}$ & & 0.49 & 0.54 & & 0.48 & 0.47 \\
\hline Overall $\mathrm{R}^{2}$ & & 0.39 & 0.44 & & 0.39 & 0.44 \\
\hline $\mathrm{F}(\mathrm{HO}$ : all coefficients $=0)$ & $\begin{array}{l}85.8 \\
(0.00)\end{array}$ & $\begin{array}{l}8.0 \\
(0.00)\end{array}$ & & $\begin{array}{l}206.9 \\
(0.00)\end{array}$ & $\begin{array}{l}7.8 \\
(0.00)\end{array}$ & \\
\hline Chi2 for model (Prob>Chi2) & & & $\begin{array}{c}177.4 \\
(0.00)\end{array}$ & & & $\begin{array}{r}152.3 \\
(0.00)\end{array}$ \\
\hline $\begin{array}{l}\text { Chi2 for Hausman test } \\
{\text { (Prob }>C h i 2)^{(b}}^{(\text {b }}\end{array}$ & & & $\begin{array}{l}17.7 \\
(0.007)\end{array}$ & & & $\begin{array}{l}22.8 \\
(0.00)\end{array}$ \\
\hline
\end{tabular}

Notes: (a Debt forgiven is scaled by gross national income (GNI) in ODA regressions and by debt stock in regressions for concessional loans.

(b Hausman test of random vs. fixed effects specification: $\mathrm{HO}=$ difference in coefficients not systematic.

The dependent variable is official development aid/GNP. The coefficient on the constant term is not reported for reason of space. The t-statistics are given in parenthesis. 
particular specification of the model. 12 The results imply that the allocation of ODA among developing countries was not affected by debt forgiveness. In other words, countries that received debt forgiveness did not receive less (or more) ODA relative to those that did not or in subsequent years following debt forgiveness. The results also show that concenssional lending was not affected by debt forgiveness. Developing countries that benefited from debt forgiveness did not receive less concessional loans following debt forgiveness or relative to those that did not receive or received less debt forgiveness.

In summary, the analysis from the recipient side shows no statistical evidence for crowding out of external development financing by debt forgiveness. The findings from the donor side discussed earlier and these results from the recipient side imply that debt forgiveness affected neither the disbursement of development assistance by donors nor the allocation of aid among recipients.

\section{Conclusion}

The debt forgiveness initiative that has been under way for over a decade has proven insufficient to resolve the debt problem of low-income countries. Even among recipients of debt relief, net transfers on debt have continued to decline. This implies that much more needs to be done to alleviate the debt burden and increase external development financing.

The evidence examined in this study indicates that the supply of ODA and grants declined in the 1990s. This downward trend of official development financing is also observed using recipient data. The flow of development aid towards HIPCs as well as towards all developing countries has declined since the 1990s. However, econometric analysis indicates no direct causal link between the volume of debt relief/forgiveness awarded and the volume of official development financing disbursed.

The decline in official development assistance to low-income countries raises serious concerns with regard to the effectiveness of the debt relief effort. The reduction in official development aid ultimately jeopardizes the purpose of debt relief because resource constraints will retard economic growth and perpetuate the dependence on external funding. Without a substantial increase in aid and other sources of low-cost external financing, the effects of debt relief on government budgets and the balance of payments are likely to be small and short lived. The gains from debt relief alone will not be enough to meet the financing needs of low-income countries and the shortage of external resources will continue to prevent the increase in domestic saving and investment that is necessary to overcome aid dependence.

Debt relief can be used to promote economic and institutional reform and enhance economic performance both among recipients of debt relief and among countries that have not yet qualified for debt relief under the HIPC Initiative. However, this will require concerted efforts by the donor community aimed at helping to transform debt relief recipients into true economic success stories. Increasing external assistance and

12 Obviously this result is conditional to this particular specification of the model. The random-effects specification might be appropriate in some alternative model of ODA allocation. 
using debt relief as a reward for performance in economic policy reform can serve as a motivation for countries that are lagging behind, inducing them to undertake economic reform programmes. Thus, debt relief can be used at both ends of the economic reform process, inducing economic reform as well as rewarding performance in economic reform.

\section{References}

Alesina, Alberto, and David Dollar (2000). 'Who Gives Foreign Aid to Whom and Why?'. Journal of Economic Growth, 5 (1): 33-64.

Alesina, Alberto, and Guido Tabellini (1989). 'External Debt, Capital Flight, and Political Risk'. Journal of International Economics, 27: 199-220.

Boyce, James K. (1992). 'The Revolving Door? External Debt and Capital Flight: A Philippine Case Study'. World Development, 20 (3): 335-45.

Boyce, James K. (1993). The Philippines: The Political Economy of Growth and Impoverishment in the Marcos Era. London: Macmillan Press.

Boyce, James K., and Léonce Ndikumana (2001). 'Is Africa a Net Creditor? New Estimates of Capital Flight from Severely Indebted Sub-Saharan African Countries, 1970-1996'. Journal of Development Studies, 38 (2): 27-56.

Burnside, Craig, and David Dollar (2000). 'Aid, Policies, and Growth'. American Economic Review, 90 (4): 847-68.

Daseking, Christina, and Robert Powell (1999). 'From Toronto Terms to the HIPC Initiative: A Brief History of Debt Relief for Low-income Countries'. IMF Working Paper 99/142. Washington, DC: IMF.

Development Committee (2002). 'Heavily Indebted Poor Countries Initiative: Status of implementation'. Washington, DC: World Bank and IMF.

Easterly, William (1999). 'How Did Highly Indebted Poor Countries Become Highly Indebted? Reviewing Two Decades of Debt Relief'. Washington, DC: World Bank. Unpublished draft.

Evans, Huw (1999). 'Debt Relief for the Poorest Countries: Why Did It Take so Long?'. Development Policy Review, 17: 267-79.

Hansen, Henrik, and Finn Tarp (2001). 'Aid and Growth Regressions'. Journal of Development Economics, 64: 547-70.

Lumsdaine, D. H. (1993). Moral Vision in International Politics. Princeton: Princeton University Press.

Maizels, Alfred, and Machiko Nissanke (1984). 'Motivations for Aid to Developing Countries'.' World Development, 879-900.

Ndikumana, Léonce (2002). 'Capital Flows, Capital Account Regimes, and Foreign Exchange Rate Regimes in Africa'. Geneva: UNCTAD. Mimeo.

Ndikumana, Léonce, and James K. Boyce (1998). 'Congo's Odious Debt: External Borrowing and Capital Flight in Zaire'.' Development and Change, 29 (2): 195-217. 
Ndikumana, Léonce, and James K. Boyce (2002). 'Public Debts and Private Assets: Explaining Capital Flight from sub-Saharan African Countries'. Research Institute, Working Paper 2002-2. Amherst: University of Massachusetts, Department of Economics and Political Economy. Forthcoming in World Development, January 2003.

Neumayer, Eric (2002). 'Is Good Governance Rewarded? A Cross-National Analysis of Debt Forgiveness'. World Development, 30 (6): 913-30.

UNCTAD (2000). Capital Flows and Growth in Africa. Geneva: United Nations.

Wolfenson, James (2001). 'Debt Relief is Being Delivered, but that's just the Start'. Washington, DC: World Bank.

World Bank (various years). World Development Indicators, CDROM edition, 1997, 2001, 2002.

World Bank (various years). Global Development Finance, CDROM edition, 2001, 2002. 
Appendix Table A1

Debt relief status (as of September 2002) and debt ratios for HIPCs (2000 values)

\begin{tabular}{|c|c|c|c|c|c|c|c|c|c|c|}
\hline Country & $\begin{array}{l}\text { Decision } \\
\text { point }\end{array}$ & $\begin{array}{l}\text { Completion } \\
\text { point }\end{array}$ & $\begin{array}{l}\text { TDS relief } \\
\text { (million \$) }\end{array}$ & $\begin{array}{l}\text { \% reduction in } \\
\text { NPV debt }\end{array}$ & $\begin{array}{l}\text { PV debt } 2000 \\
\text { (million \$) }\end{array}$ & $\begin{array}{c}\text { TDS/XGS } \\
(\%)\end{array}$ & $\begin{array}{c}\text { INT/XGS } \\
(\%)\end{array}$ & $\begin{array}{c}\text { INT/GNP } \\
(\%)\end{array}$ & $\begin{array}{c}\text { EDT/XGS } \\
(\%)\end{array}$ & $\begin{array}{c}\text { EDT/GNP } \\
(\%)\end{array}$ \\
\hline \multicolumn{11}{|c|}{ Completion point reached under enhanced framework $(n=6)$} \\
\hline $\begin{array}{l}\text { Bolivia } \\
\quad \text { (Enhanced) }\end{array}$ & $\begin{array}{l}\text { Sep. } 97 \\
\text { Feb. } 00\end{array}$ & $\begin{array}{l}\text { Sep. } 98 \\
\text { Jun. } 01\end{array}$ & $\begin{array}{r}760 \\
1,300\end{array}$ & $\begin{array}{l}14 \\
30\end{array}$ & 2,750 & 39.1 & 11.1 & 2.3 & 340.1 & 71.5 \\
\hline $\begin{array}{c}\text { Burkina Faso } \\
\text { (Enhanced) } \\
\text { (Topping up) }\end{array}$ & $\begin{array}{l}\text { Sep. } 97 \\
\text { Jul. } 00\end{array}$ & $\begin{array}{l}\text { Jul. } 00 \\
\text { Apr. } 02 \\
\text { Apr. } 02\end{array}$ & $\begin{array}{l}400 \\
300 \\
230\end{array}$ & $\begin{array}{l}27 \\
30\end{array}$ & 663 & 17.3 & 4.9 & 0.7 & 421.8 & 61.3 \\
\hline Mauritania & Feb. 00 & Floating & 1,100 & 50 & 1,220 & 25.9 & 8.5 & 3.6 & 645.0 & 275.1 \\
\hline $\begin{array}{l}\text { Mozambique } \\
\text { (Enhanced) }\end{array}$ & $\begin{array}{l}\text { Apr. } 98 \\
\text { Apr. } 00\end{array}$ & $\begin{array}{l}\text { Jun. } 99 \\
\text { Sep. } 01\end{array}$ & $\begin{array}{r}3,700 \\
660\end{array}$ & $\begin{array}{l}63 \\
27\end{array}$ & 1,160 & 11.4 & 4.0 & 0.9 & 927.8 & 198.1 \\
\hline Tanzania & Apr. 00 & Nov. 01 & 3,000 & 54 & 4,490 & 16.2 & 4.6 & 0.7 & 555.7 & 82.9 \\
\hline $\begin{array}{l}\text { Uganda } \\
\text { (Enhanced) }\end{array}$ & $\begin{array}{l}\text { Apr. } 97 \\
\text { Feb. } 00\end{array}$ & $\begin{array}{l}\text { Apr. } 98 \\
\text { May } 00\end{array}$ & $\begin{array}{r}650 \\
1,300\end{array}$ & $\begin{array}{l}20 \\
37\end{array}$ & 984 & 23.6 & 6.8 & 0.7 & 506.1 & 55.4 \\
\hline \multicolumn{11}{|c|}{ Decision point reached under enhanced framework $(n=20)$} \\
\hline Benin & Jul. 00 & Floating & 460 & 31 & 976 & 12.6 & 3.2 & 0.9 & 263.4 & 74.4 \\
\hline Cameroon & Oct. 00 & Floating & 2,000 & 27 & 6,250 & 20.5 & 10.6 & 3.5 & 337.5 & 111.6 \\
\hline Chad & May 01 & Floating & 260 & 30 & 587 & 9.3 & 3.6 & 0.7 & 394.3 & 79.9 \\
\hline Ethiopia & Nov. 01 & Floating & 1,930 & 47 & 3,260 & 13.9 & 5.3 & 0.8 & 548.0 & 86.6 \\
\hline Gambia & Dec. 00 & Floating & 90 & 27 & 265 & 6.9 & 2.5 & 1.6 & 176.1 & 113.4 \\
\hline Ghana & Feb. 02 & Floating & 3,700 & 56 & 3,920 & 19.2 & 6.4 & 3.1 & 271.6 & 132.2 \\
\hline Guinea & Dec. 00 & Floating & 800 & 32 & 2,340 & 15.3 & 6.5 & 1.9 & 389.4 & 115.6 \\
\hline Guinea-Bissau & Dec. 00 & Floating & 790 & 85 & 700 & 8.6 & 3.7 & 1.3 & $1,305.1$ & 463.5 \\
\hline $\begin{array}{l}\text { Guyana } \\
\text { (Enhanced) }\end{array}$ & $\begin{array}{l}\text { Dec. } 97 \\
\text { Nov. } 00\end{array}$ & $\begin{array}{l}\text { May } 99 \\
\text { Floating }\end{array}$ & $\begin{array}{l}440 \\
590\end{array}$ & $\begin{array}{l}24 \\
40\end{array}$ & 842 & $\begin{array}{r}19.4 \\
(1998)\end{array}$ & $\begin{array}{r}9.0 \\
(1998)\end{array}$ & 7.3 & $\begin{array}{r}236.2 \\
(1998)\end{array}$ & 220.5 \\
\hline Honduras & Jul. 00 & Floating & 900 & 18 & 3,110 & 19.3 & 6.4 & 3.3 & 183.5 & 94.7 \\
\hline Madagascar & Dec. 00 & Floating & 1,500 & 40 & 2,990 & 7.7 & 3.1 & 1.0 & 388.4 & 123.6 \\
\hline Malawi & Dec. 00 & Floating & 1,000 & 44 & 1,490 & 11.7 & 4.1 & 1.2 & 543.3 & 163.6 \\
\hline $\begin{array}{l}\text { Mali } \\
\quad \text { (Enhanced) }\end{array}$ & $\begin{array}{l}\text { Sep. } 98 \\
\text { Sep. } 00\end{array}$ & $\begin{array}{l}\text { Sep. } 00 \\
\text { Floating }\end{array}$ & $\begin{array}{l}220 \\
650\end{array}$ & $\begin{array}{r}9 \\
28\end{array}$ & 1,340 & 12.1 & 3.4 & 1.2 & 367.7 & 130.8 \\
\hline Nicaragua & Dec. 00 & Floating & 4,500 & 72 & 5,550 & 23.0 & 8.3 & 5.2 & 538.3 & 332.6 \\
\hline
\end{tabular}


Appendix Table A1 (con't)

Debt relief status (as of September 2002) and debt ratios for HIPCs (2000 values)

\begin{tabular}{|c|c|c|c|c|c|c|c|c|c|c|}
\hline Country & $\begin{array}{l}\text { Decision } \\
\text { point }\end{array}$ & $\begin{array}{l}\text { Completion } \\
\text { point }\end{array}$ & $\begin{array}{l}\text { TDS relief } \\
\text { (million \$) }\end{array}$ & $\begin{array}{l}\text { \% reduction in } \\
\text { NPV debt }\end{array}$ & $\begin{array}{l}\text { PV debt } 2000 \\
\text { (million \$) }\end{array}$ & $\begin{array}{c}\text { TDS/XGS } \\
(\%)\end{array}$ & $\begin{array}{c}\text { INT/XGS } \\
(\%)\end{array}$ & $\begin{array}{c}\text { INT/GNP } \\
(\%)\end{array}$ & $\begin{array}{c}\text { EDT/XGS } \\
(\%)\end{array}$ & $\begin{array}{c}\text { EDT/GNP } \\
(\%)\end{array}$ \\
\hline \multicolumn{11}{|c|}{ Decision point reached under enhanced framework $(n=20)$} \\
\hline Niger & Dec. 00 & Floating & 900 & 54 & 1,040 & 9.4 & 3.4 & 0.6 & 534.6 & 89.0 \\
\hline Rwanda & Dec. 00 & Floating & 800 & 71 & 722 & 24.7 & 7.8 & 0.6 & 896.2 & 71.6 \\
\hline $\begin{array}{l}\text { Sao Tome and } \\
\text { Principe }\end{array}$ & De. 00 & Floating & 200 & 83 & 196 & 31.7 & 15.1 & 4.8 & $2,273.2$ & 726.1 \\
\hline Senegal & Jun. 00 & Floating & 850 & 19 & 2,420 & 14.4 & 4.7 & 1.7 & 213.4 & 78.7 \\
\hline Sierra Leone & Mar. 02 & Floating & 950 & 80 & 792 & 48.0 & 11.0 & 1.6 & $1,434.7$ & 206.6 \\
\hline Zambia & Dec. 00 & Floating & 3,850 & 63 & 5,000 & 18.7 & 8.9 & 3.1 & 578.1 & 205.3 \\
\hline \multicolumn{11}{|c|}{ Decision point reached under original framework $(n=1)$} \\
\hline Côte d'Ivoire & Mar. 98 & - & 800 & 6 & 11,538 & 22.4 & 11.8 & 6.3 & 266.8 & 140.9 \\
\hline \multicolumn{11}{|c|}{ Countries still to be considered $(n=11)$} \\
\hline Burundi & & & & & 644 & 37.2 & 13.5 & 1.2 & 1910.9 & 163.3 \\
\hline $\begin{array}{l}\text { Central African } \\
\text { Republic }\end{array}$ & & & & & 543 & 12.9 & 3.8 & 0.6 & 556.4 & 91.6 \\
\hline Comoros & & & & & 157 & 5.0 & 2.4 & 0.6 & 428.9 & 114.6 \\
\hline $\begin{array}{l}\text { Congo, Dem. } \\
\text { Rep. }^{(a)}\end{array}$ & Jan. 02 & & $(9,800)$ & $(79)$ & 10,900 & na & $\begin{array}{r}1.1 \\
(1998)\end{array}$ & $\begin{array}{r}0.3 \\
(1998)\end{array}$ & $\begin{array}{r}777.2 \\
(1998)\end{array}$ & $\begin{array}{r}208.2 \\
(1998)\end{array}$ \\
\hline Congo, Rep. & & & & & 4,600 & 1.6 & 1.4 & 1.7 & 179.7 & 219.0 \\
\hline Lao PDR & & & & & na & na & 1.9 & 0.6 & 484.1 & 149.6 \\
\hline Liberia & & & & & na & na & na & na & na & na \\
\hline Myanmar & & & & & 4,340 & 4.7 & 0.9 & na & 327.6 & na \\
\hline Somalia & & & & & 2,270 & na & na & na & na & na \\
\hline Sudan & & & & & 14,800 & 3.2 & 0.1 & 0.0 & 829.8 & 161.4 \\
\hline Togo & & & & & 1,020 & 6.1 & 2.1 & 0.9 & 294.7 & 120.1 \\
\hline Total debt relief & & & 415,200 & & & & & & & \\
\hline
\end{tabular}

Note: $\quad$ a DRC: preliminary HIPC paper issued and expecting $\$ 9.8$ billion in debt relief .

Sources: $\quad$ World Bank, Global Development Finance 2002; IMF and World Bank HIPC decision and completion documents. 